\title{
MINIMIZATION OF WORK PROCESS TIME USING LEAN MANUFACTURING TOOL
}

\author{
K.R Dushyanth Kumar ${ }^{1}$, G.S Shivashankar ${ }^{2}$, Rajeshwar S Kadadevarmutt ${ }^{3}$ \\ ${ }^{1}$ Department of Mechanical Engineering, Malnad College of Engineering, Hassan, Karnataka, 573201, India \\ ${ }^{2}$ Department of Mechanical Engineering, Malnad College of Engineering, Hassan,, Karnataka, 573201, India \\ ${ }^{3}$ Professor, Department of IEM,SIT, Tumukuru
}

\begin{abstract}
Small amd medium scale enterprices(SMEs) are the backbone of the economy system. in context with consistency and its survival they are struggling before the customer market, because of the poor maintenance of quality and accuracy of the product and also varieties andvariations of the products in customer views. Due to increased customer demands, high product variety, and a push production system, the organizations have been suffering from excessive wastes, poor working environment, Which increases the production cost and product delays also, Under such conditions, improvement in existing working systems through the continuous improvement techniques are most usefull. in this regard the use of lean manufacturing techniques are more effective for the SMEs. in this work we are using $5 S$ as a lean tool for achieving the work flow, cleaning the production process by removing wastes in the organization. Which represents a fundamental technique to enhancing the of efficiency and productivity, with systematic organizational work culture. In this reaserch work, we are aiming to review the applications of $5 S$ study and its efficiency in the various organizations, then through the case study of medium organization how the efficiency and productivity performance can possible is achieved in with good results.
\end{abstract}

Keywords : Quality improvement, 5S, Lean manufacturing tool.

\section{INTRODUCTION}

On the basis of continuous improvement technique like Total Quality Management (TPM), most of the work standards and their maintenance problems are solved in easy manner with lesser cost (J. Michalska D. and Szewieczek 2007), Here maximum equipment efficiency can obtain in an organizations, where an integrity of effective and autonomous maintenance is considered through the small group activities. In TPM all parties are participated with effe ctive way to maximize the productivity with good efficiency. Mainly which involes skilled operators in work environment with a good work standards in work environment, and most of the time self maintenance and involment is required as a special skill for an employee. but further improvement in this regard on operating level in work atmosphere will becomes more popular. In this regard the use of advanced manufacturing techniques are popular and effective. Among all the techniques lean manufcaturig is most effective and less expensive. in this way the $5 \mathrm{~s}$ is one of the effective lean tool, which were first developed by Hiroyuki Hirano. Initially this technique was originated from Japan. The $5 \mathrm{~S}$ is the methodology of creation and maintaining well organized, clean, high effective and high quality workplace. Its result is the effective workplace in organization. Here elimination of wastes in manufacturing process is required, which leads to the quality and safety of work environment (T. Karkoszka, D. Szewieczek 2007). The basic principle is good house keeping around the work stations, that will result in reduction of waste, better cleanliness and creation of a culture to sustain long time. The philosophy of the $5 \mathrm{~S}$ has its roots in Japan, which is an effective tool in lean manufacturing for the programme of improvement in the quality and accuracy in products. The $5 \mathrm{~s}$ means keep the work environment with less space with proper arrangement which leads to minimization of time in particular task with error free products with good quality. (Brah SA, Chong WK 2004) disciplined and clean. Actually in first stage the requirement to the work place is decided, next stage providing best support to the functions and finally identification of root cause and best solution is provided. (Bayo-Moriones et al. 2010). The total study of the 5s aims to analysis of previous drawbacks in the process of work stations and improve its efficiency of an organization. 5S is a Japanese Management Philosophy for safe Working Environment suited for especially shared work place like shop floor, office space. Originated from Japanese housekeeping idea their meanings are Seiri (sort), Seiton (set in order), Seiso (shine), Seiketsu (standardize), Shitsuke (sustain). For reducing ineffective time or waste in process. 5S application will improves personal standards and motivation to operators in their workplace and definitely which is an high impact on work area, work safety, quality, efficiency through the continuous observation with the effective team work. This work aims to study the previous works of $5 \mathrm{~s}$ principle and their effects in organizations and the application of $5 \mathrm{~s}$ tool to the medium organization and its improvement is made in simple manner with proper case study.

\subsection{Implementation of $5 \mathrm{~s}$}

$5 \mathrm{~s}$ is the standardized philosophy, through wich we can achive effective and clean, systematic work environment in simple manner. Here the planning and organization of work activities can decrease the time and improves the product 
quality proper planning functions with good results for the customer satisfaction as per their desired products. $5 \mathrm{~S}$ is a lean tool, which delivers results by a systematic approach of planning and organizing the activities. $5 \mathrm{~s}$ is a lean tool which can reduces the waste in process and improves quality and accuracy of product. Thetotal meaning of the $5 \mathrm{~s}$ system is discussed below in simple way.

\subsection{SEIRI (Sorting and disposing unnecessary} items)

This is the initial step to remove the materials which are most un wated for the manufacturing purpose, the equipments, materials and tools are first sorted and placed acordingly in their workplace which reduces searching time

\subsection{SEITON (Set in order, Orderliness)}

Keep everything must be in proper place for quick identification for work process. Materials, tools and equipments are arrangedin systematic manner to serch easily for work and access them quickly, so work flow is easy and effective

\subsection{SEISO (Shining, Cleaning, Removal of waste and dust)}

For good impression in work atmosphear, the cleaning shoud be a daily routine activity. After the use of any tools and equipment, they must stored in proper place.

\subsection{SEIKETSU (Consistent and Standardized work}

\section{environment along with Cleanliness)}

Seiketsu encompasses a clean and regular working and living environment, both personal and environmental cleanliness. This is because dust, dirt and wastes are the source of untidiness, indiscipline, inefficiency, faulty production and work accidents

\subsection{SHITSUKE (Sustain,the above rules must}

\section{keepwith consistancy)}

This $5 \mathrm{~s}$ application will motivate the employees decipline, so that they can abey the set of rules frame dby this principles.

\section{LITERATURE REVIEW}

By the various author,s work, the contribution of $5 \mathrm{~s}$ to the organizations are discussed with better productivity results in different manner. As per their achievements the $5 \mathrm{~s}$ application to small and medium organizations are motivated to our work. Because the the $5 \mathrm{~s}$ application is more quality and accuracy concerned. The well ordered decipline and minimum defects are occurred while using $5 \mathrm{~s}$ principle (Chapman, C.D 2005). 5s is a management provision technique in the manufacturing system, which reduces product complexity in work flow and giving perfect accuracy and more productivity with minimum time possibility (Gapp, R et al. 2008). The use of 5s application is more better than a use of management principles (Kumar, M., et al 2006). The initial journey of 5s starts at Japanese house keeping works and most of the time it links with JIT and TPM related activities (Gapp, $\mathrm{R}$ et al. 2008). In case of data management techniques the $5 \mathrm{~s}$ performance is more effective and proved with standard way with higher performance efffciency, and improvement of data processing work is focused clearly in simple manner (Ananthanarayanan 2006). In daily acyivities of the main organizations in all over the countries are practiced the $5 \mathrm{~s}$ technique and got the good results also (Ho, S.K.M., 1999). The $5 \mathrm{~s}$ application comes through the lean manufacturing principles and its norms. The minimization of non vaue added things to the product manufacturing system is focused in $5 \mathrm{~s}$ practice and their study in all aouthor,s views, and which increases quality, accuracy and reduces all types of pollutions in the work environment of an organizations. (Nilipour, A. and M. Jamshidian 2005). The hongkong companies are practiced this $5 \mathrm{~s}$ technique and got improved product quality in minium time in most cases. The $5 \mathrm{~s}$ application in case of manufacturing and service sectors aso discussed in big business sectors (Ho, S.K et al. 1995). The malasian government also keen with the application of 5 s tool to their industrial reaserch institute standars for their improvements. (Ho, S.K. and S. Cicmil 1996). In small and medium scale industries they are not having more capitals to the new technologies, and they are waiting for the product profits to take up the challenges (Chauhan et al 2010). The development of key ares of manufacturing needs the new manufacturing philosophies and practices for the efficiency enhancement (Hudli and Imandar 2010). In case of plastic moulding industry, the significant effect on the productivity with less time is achived in their working systems were discussed in author,s case study (Khedkar et al 2012). In the above studies there must be a gap between the employees in their working environment which causes wasting resources, time and money with defective parts in nature. Another significant barrier poor awareness in training nature between top management and workers in shop floor. Therefore, it is believed that skilled training is needed for the employees working culture through the application of $5 \mathrm{~s}$ principles. (Nilipour, A. and M. Jamshidian). The complete progress of all $5 \mathrm{~s}$ tool is explained through the clear calculation (Prashant Koli 2012), But Especially in SMEs improvement in productivity with reduced cycle time can achieved by the help of 5S technology implementation in effective manner is required for their existence in market with customer pull system manner. Through $5 \mathrm{~s}$ methodology significance effectiveness achieved workplace improvement of small organization is discussed (S. Agrahari et al.) and achived the good results in productivity. $5 \mathrm{~S}$ technique has been strongly supports to achive employee performance in organization as a quality management tool (P. Rai,2016). The 5S describes how items are stored and how the new order is maintained. It reduces the service time and increase organization culture in continuous improvement criteria (Ravi Chourasia, Dr. Archana Nema ,2016)

\section{COMPANY AND PROCESS BACKGROUND}


In city municipality organization of Hassan, Karnataka, around 40 elected members in this organization and the functions of this enterproces were well organized $y$ the officials.Thefunctions of muncipalty organization are given below in Table. 1

Table 1: Details of municipal organization funtions

\begin{tabular}{|l|l|}
\hline Details /Functions of CMC & Capacity \\
\hline City Population & $1,55,000$ \\
\hline Geographical area & $30.6 \mathrm{Sq} \mathrm{km}$ \\
\hline Assets count & 28,835 \\
\hline Total wards & 35 \\
\hline Road length & $302 \mathrm{Km}$ \\
\hline Supply of water & 17.8 MLD (Million \\
& Liter/Day) \\
\hline Per Capita Water Supply & 135 LPCD (Liter Per \\
& Capita /Day) \\
\hline
\end{tabular}

\subsection{Problem Descriptions}

From the past years, lean manufacturing and SCM concepts were incorporated in medium and large scale industries, but in case of SME,s and public enterprises are very limited in nature and very challenging also.Here the present work focuses with public problems and their requirements in the office of City Municipal Corporation (CMC) at Hassan. As per the above table. 2.1 The most of the customer problems and their needs are associate with public related and answering them in documentation form in CMC office is very difficult problem. To resolving the public problem, maintenance of records in record room in systematic manner is needed, and also searching files with in a short time is also essential to minimize the cycle time in office. in CMC office the files are stored in bulk manner randomly at record room which is very difficult to searching the required files with in a short time and the maintenance is also very poor manner as shown in below Fig. 1

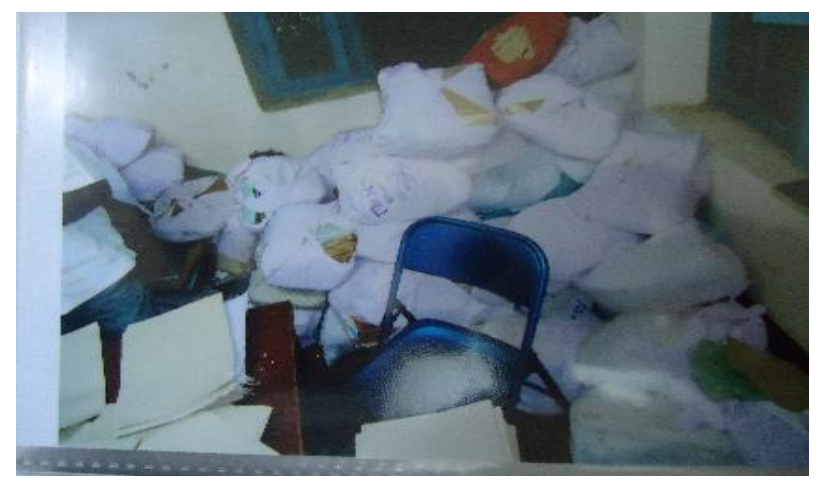

Fig.1: Poor maintenance of records in record room

\subsection{Objectives}

In current days, the customers are highly concern with the expectation of quick and quality service from the organization, for which the public enterprises have to improve their efficiency related with their system in their working environment. This research work is related to problems of CMC office hassn for their poor maintenance of record documentation for publics' requirements, hence which is required to improve the working system in the $\mathrm{CMC}$ office through the incorporation of $5 \mathrm{~S}$ principle from the lean manufacturing. Here in this case study the main objective is to reducing the total cycle time required to searching the required record from the record room. For which analysis of old records maintenance and its searching is essential after that finding a technical solution and apply the simple and systematic approach is proved in simple manner is considered.

\section{METHODOLOGY}

Here getting productivity by reducing the file searching time and its maintenance using simple $5 \mathrm{~S}$ concept is used to improve the problem of publics. Here study of old system of record maintenance and its service to publics are considered. Hence the sorting technique is applying through the incorporation of $5 \mathrm{~S}$ principle. Then the removal of non value added activities in the office system of CMC, hassan and showing the improvement in the record maintenance and its service to publics are shown in the below flow diagram of methodology in Fig. 2

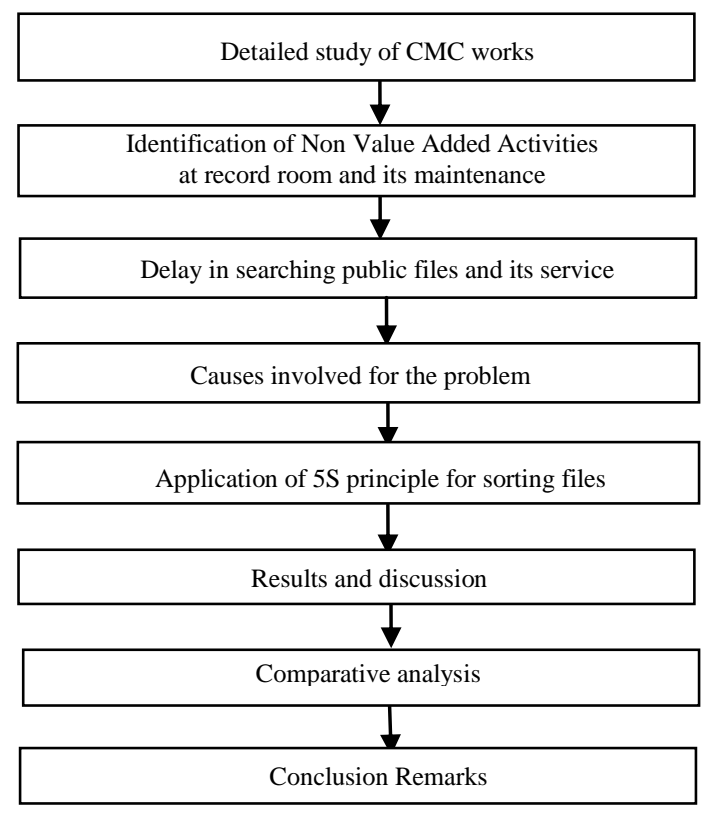

Fig. 2 : Methodology

\subsection{Data Collection, Analysis and}

\section{Implementation}

To improve the efficiency in a simple manner in any system or organization is the most challenging task, which requires the previous data's and its analysis with the real documentation. Here the fallowing record room data,s like descriptions of all papers of 5 years to 30 years documentations are needed as per the guidance of Karnataka municipalities (Guidance of officers, Grant of copies and miscellaneous provisions) (Amendment ) Rules, 1967, Karnataka gazette are given in Table. 2

Table 2: Papers descriptions of municipal guidance \begin{tabular}{|l|l|l|}
\hline Paper & Validity & Descriptions of papers \\
\hline
\end{tabular} 


\begin{tabular}{|l|l|l|}
\hline "A" Papers & Permanent & $\begin{array}{l}\text { Register of proceedings of } \\
\text { municipal council, } \\
\text { Records expenditure on } \\
\text { works, claims of sevice } \\
\text { persons. }\end{array}$ \\
\hline "B" Papers & 30 years & $\begin{array}{l}\text { Collection of register of } \\
\text { taxes, Licenses, } \\
\text { miscellaneous sales, } \\
\text { Assessment list of } \\
\text { buildings and lands liable } \\
\text { to tax files with }\end{array}$ \\
\hline "C" Papers & 10 years & $\begin{array}{l}\text { Work files } \\
\text { estimation of municipal, } \\
\text { workspublic }\end{array}$ \\
\hline "D" Papers & 5 years & $\begin{array}{l}\text { Bill of payment of } \\
\text { suppliers on construction, } \\
\text { reconstructions. }\end{array}$ \\
\hline "E" Papers & 1 year & $\begin{array}{l}\text { Daily reports of plague, } \\
\text { cholera and small pox, } \\
\text { annual administration } \\
\text { works }\end{array}$ \\
\hline
\end{tabular}

\subsection{Data Analysis}

From the above set of data's collected is in form of papers descriptions and kept in respective files. Totally around 1, 00000 files were stored in record room randomly. Searching of 1980-82 data with respect to one customer is required 30 days in one simple case. Maintenance of files is not in a systematic manner, there are no numbering, labeling, bundles and files with the particular racks as per the order of priority basis considerations.

\subsection{5s Technology Implementation to Process}

After the data processing, the different $5 \mathrm{~S}$ terminologies are suitable with the functions of CMC hassan and the details of the various functionalities are described in the below table for the exact $5 \mathrm{~S}$ applications to reducing the wastes through the proper destruction of files after that the exact systematic arrangement of files and maintain consistency throughout the work environment process is obtained in simple manner is explained in the Table. 3

Table 3: 5S implementation to CMC functions

\begin{tabular}{|l|l|}
\hline 5S Terminologies & Suitable CMC functions \\
\hline $\begin{array}{l}\text { SEIRI (Sorting and } \\
\text { disposing unnecessary } \\
\text { items) }\end{array}$ & Segregation of files \\
\hline $\begin{array}{l}\text { SEITON (Set in order, } \\
\text { Orderliness) }\end{array}$ & $\begin{array}{l}\text { Numbering, Labeling, } \\
\text { Bundling of files }\end{array}$ \\
\hline $\begin{array}{l}\text { SHITSUKE (Sustain, } \\
\text { realization of the above } \\
\text { set of rules in order) }\end{array}$ & $\begin{array}{l}\text { Preparation of check lists } \\
\text { and } \\
\text { files arrangement in } \\
\text { proper racking system }\end{array}$ \\
\hline $\begin{array}{l}\text { SEIKETSU (Consistent } \\
\text { and Standardized work } \\
\text { environment along with } \\
\text { Cleanliness) }\end{array}$ & Application of software \\
\hline SEISO: (Shining, & Closing or destruction of \\
\hline
\end{tabular}

\begin{tabular}{|l|l|l|}
\hline $\begin{array}{l}\text { Cleaning, Removal of } \\
\text { waste and dust) }\end{array}$ & files \\
\hline
\end{tabular}

\subsection{Data Processing Approach}

After collecting respective files of papers descriptions, the files segregation process in record room starts with systematic manner through the fallowing different steps as fallows

- Segregation of files

- Numbering of files

- Preparation of check lists

- Application of software

- Labeling of files

- Bundling of files

- Files arrangement in proper racking system

- Closing or destruction of files

\subsection{Segregation of files}

Initially segregation process starts systematically as per the year wise, ward wise, subject wise and type wise as per the Table. 4

Table 4: File segregation descriptions

\begin{tabular}{|l|l|}
\hline Sl.no. & Descriptions \\
\hline Year wise & From 85-86 to 2014-15 \\
\hline Ward wise & Total 35 ward wise \\
\hline Subject wise & $\begin{array}{l}\text { Engineering, SAS declaration, accounts, } \\
\text { mutation }\end{array}$ \\
\hline Type wise & $\begin{array}{l}\text { A type, B type, C type, D type, E type as } \\
\text { per permanent, 30, 10, 5, and 1 year } \\
\text { storage types respectively }\end{array}$ \\
\hline
\end{tabular}

\subsection{Numbering of Files}

Particular page numbers are allotted from first page to last pages as per type of files of every year. serial numbers are given from starting page to ending page of the complete year after that fresh number is allotted to next year file.

\subsection{Preparation of Check Lists}

Check list fallows the 18 columns with their details as fallows in Table. 5

Table 5: Chechlist formulation

\begin{tabular}{|l|l|l|}
\hline $\begin{array}{l}\text { Sl.n } \\
\text { o. }\end{array}$ & Contents & Details \\
\hline 1 & Office name & Hassan municipality \\
\hline 2. & subject type file & Dutation, bill payment.. \\
\hline 3. & $\begin{array}{l}\text { date of first page of file } \\
\text { commencement }\end{array}$ & Type, year, ward wise. \\
\hline 4. & File number & Respective ward \\
\hline 5. & Ward number & Name, address.. \\
\hline 6. & subject details & Type of files \\
\hline 7. & Movement & $\begin{array}{l}\text { Date of last page of the } \\
\text { file }\end{array}$ \\
\hline 8. & Date of closing \\
\hline
\end{tabular}




\begin{tabular}{|c|c|c|}
\hline 9. & $\begin{array}{l}\text { Total number of } \\
\text { pages in file }\end{array}$ & First page to last page \\
\hline 10. & Paragraph & \\
\hline 11. & $\begin{array}{l}\text { Color scanning } \\
\text { pages }\end{array}$ & \\
\hline 12. & $\begin{array}{l}\text { White and black } \\
\text { scanning }\end{array}$ & \\
\hline 13. & $\begin{array}{l}\text { Date of file } \\
\text { destruction }\end{array}$ & Type wise \\
\hline 14. & $\begin{array}{l}\text { Date of receive in } \\
\text { record room }\end{array}$ & $\begin{array}{l}\text { Date of file transfer to } \\
\text { record room }\end{array}$ \\
\hline 15. & $\begin{array}{l}\text { Date of } \\
\text { acknowledgement } \\
\text { receipt }\end{array}$ & \\
\hline 16. & Racking numbers & As per 35 wards \\
\hline 17. & Roll number & Mention rack number \\
\hline 18. & Bundle number & $\begin{array}{l}\text { Mention bundle number } \\
\text { (100 files per bundle) }\end{array}$ \\
\hline
\end{tabular}

\subsection{Labeling of Files}

Different colors are used to label the files as per their types, 100 files per one bundle and each bundles are with separate label should prepare. And labels are highlighting the details of check list given in Table 6

Table 6: Check list details

\begin{tabular}{|l|l|}
\hline Type of files & Colors used \\
\hline A type & Red (Permanent files) \\
\hline B type & Green $(30$ years $)$ \\
\hline C type & Yellow (10 years) \\
\hline D type & White (5 years) \\
\hline E type & Blue (1 year) \\
\hline
\end{tabular}

\subsection{Bundling of Files}

The distributed files in random manner at record room were bundling as per the year wise as shown below Fig. 3

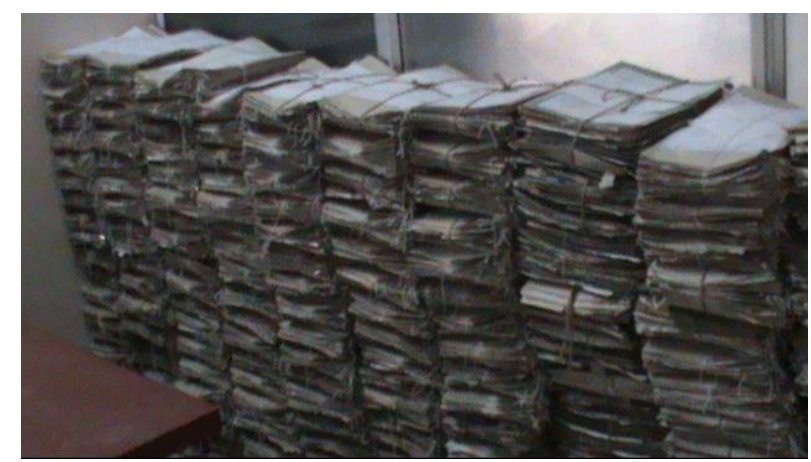

Fig.3: File Bundling process

\subsection{Files Arrangement in Proper Racking System}

1 to 35 numbers are allotted as per the total number of wards in hassan city. As per their storage pattern time with color code shown below Fig. 4, 5, 6,7 and 8

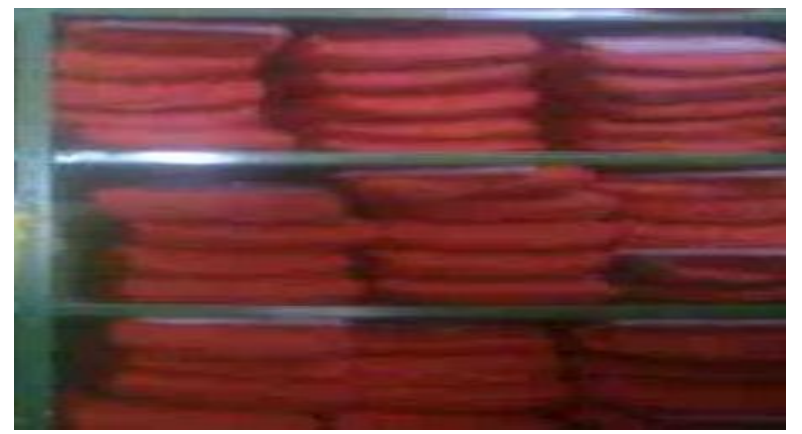

Fig.4 : Permanent storage files

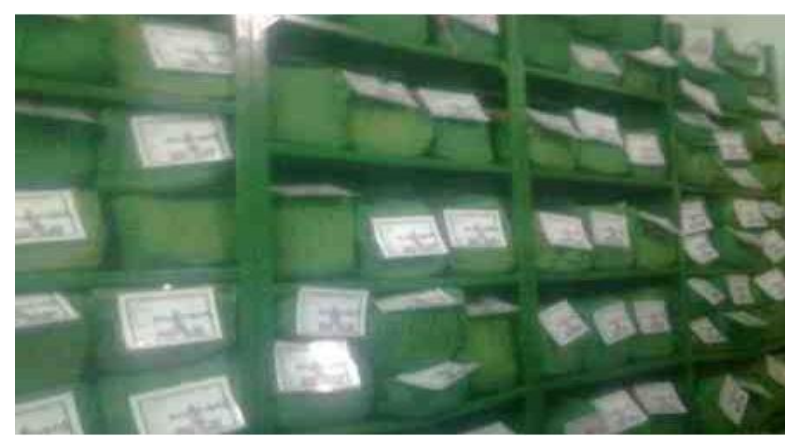

Fig.5 : Storage files up to 30 years

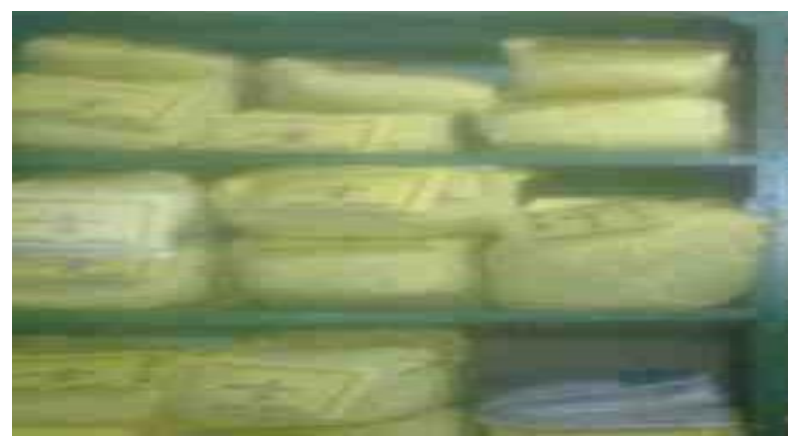

Fig. 6 : Storage files up to 10 years

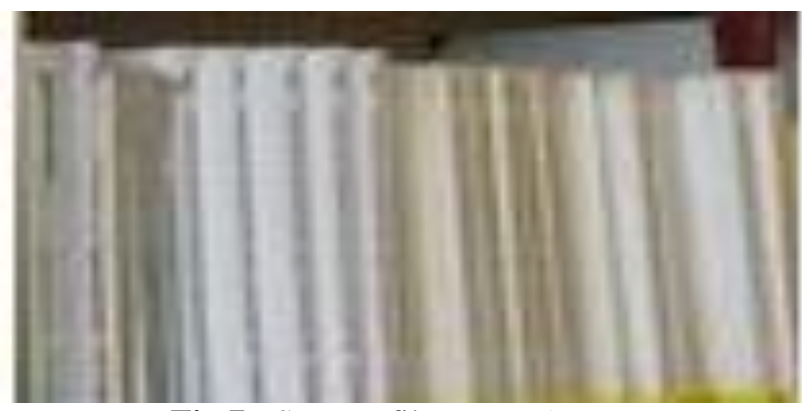

Fig.7: Storage files up to 5 years

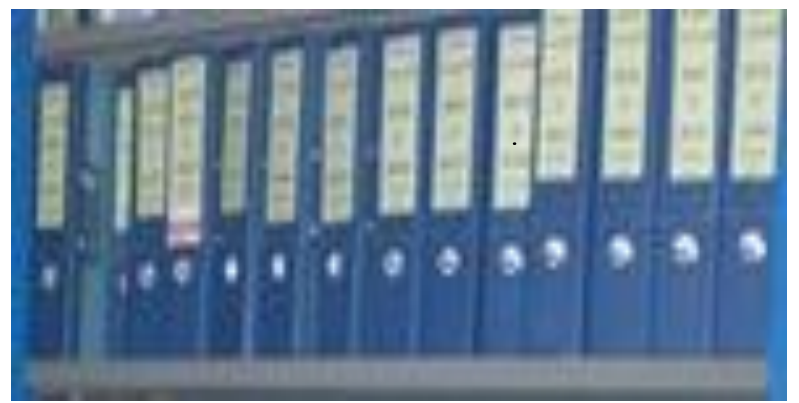

Fig.8 : Storage files up to 1 year 


\subsection{Closing or Destruction of Files}

For 30 years old files are destroyed as per the higher instructions some of the images of files storage in racks with their color identifications are given below sketches

\subsection{Software Application}

On the basis of the check list the considering the input factors for the software application using Visual basic programme is discussed and this software application programme fallows the three steps like, steps to fallow (input), details of requirement (output) and software development details are given below

\section{a) Steps to fallow (input)}

As per the customer requirements the input for the development of software to get the particular output are mentioned in in Table. 7

Table 7: Steps to fallow for programme development

\begin{tabular}{|c|c|}
\hline $\begin{array}{l}\text { Select year (from } \\
\text { drop down box) }\end{array}$ & Box should show $1990-2016$ \\
\hline $\begin{array}{l}\text { Select } \\
\text { Department } \\
\text { (from drop down } \\
\text { box) }\end{array}$ & Municipal Department \\
\hline $\begin{array}{l}\text { Category (from } \\
\text { drop down box) }\end{array}$ & $\begin{array}{l}\text { 1) Health 2)revenue 3)accounts } \\
\text { 4)administration }\end{array}$ \\
\hline $\begin{array}{l}\text { Sub Category } \\
\text { (from drop down } \\
\text { box) }\end{array}$ & $\begin{array}{l}\text { 1) Health-trade license, vehicle } \\
\text { log box.. } \\
\text { 2) Schemes-finance.. } \\
\text { 3) Engineering } \\
\text { wards, vehicle books.. } \\
\text { 4) Revenue-khatha exchange, } \\
\text { SAS declaration.. } \\
\text { 5) IT-GIS-birth and death sakala.. }\end{array}$ \\
\hline \multicolumn{2}{|l|}{ File number } \\
\hline \multicolumn{2}{|l|}{$\begin{array}{l}\text { File register } \\
\text { number }\end{array}$} \\
\hline \multicolumn{2}{|l|}{ Subject } \\
\hline $\begin{array}{l}\text { Nature of deposit } \\
\text { (from drop down } \\
\text { box) }\end{array}$ & A B C D E \\
\hline \multicolumn{2}{|l|}{ Date of disposal } \\
\hline 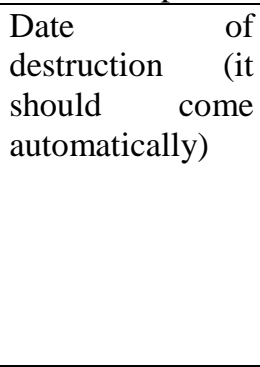 & $\begin{array}{l}\text { 1) if we enter nature of disposal } \\
\text { as A this column disables } \\
\text { 2) if we enter nature of disposal } \\
\text { as B this column disables, it should } \\
\text { count from date of disposal and } \\
\text { show } 30 \text { years } \\
\text { 3) same way for C } 10 \text { years } \\
\text { 4) for D } 5 \text { years } \\
\text { 5) for E } 1 \text { year }\end{array}$ \\
\hline $\begin{array}{l}\text { 6) Number of } \\
\text { pages }\end{array}$ & 7) Number of pages in a file \\
\hline $\begin{array}{l}\text { 8) Record } \\
\text { room serial } \\
\text { number }\end{array}$ & 9) \\
\hline 10) Record & 11) \\
\hline
\end{tabular}

\begin{tabular}{|ll|l|}
\hline $\begin{array}{l}\text { room } \\
\text { number }\end{array}$ & row & \\
\hline
\end{tabular}

\section{b) Programme development}

Private Sub cbocategoryID_After Update( )

'Set the subcategory combo box to be limited by the selected category

Me.cbosubcategoryID.RowSource = "SELECT tblsubcategory.subcategoryID,

tblsubcategory.subcategoryName FROM tblsubcategory " \&

" WHERE categoryID = " \& Nz(Me.cbocategoryID) \&

" ORDER BY subcategoryName"

Me.cbosubcategoryID = Null

EnableControls

End Sub

Private Sub cbocategoryID_BeforeUpdate(cancel As Integer)

End Sub

Private Sub cbodistrictID_AfterUpdate()

'Set the taluk combo box to be limited by the selected district

Me.cbotalukID.RowSource = "SELECT tbltaluk.talukID, tbltaluk.talukName FROM tbltaluk " \& _ " WHERE districtID $=$ " \& Nz(Me.cbodistrictID) \&

" ORDER BY talukName"

Me.cbotalukID $=$ Null

EnableControls

End SubPrivate Sub EnableControls( )

'Clear the combo boxes

If IsNull(Me.cbocategoryID) Then

Me.cbosubcategoryID = Null

End If

'Enable or disable combo boxes based on whether the combo box preceeding it has a value.

Me.cbosubcategoryID.Enabled

IsNull(Me.cbocategoryID))

If IsNull(Me.cbodistrictID) Then

Me.cbotalukID = Null

End If

'Enable or disable combo boxes based on whether the combo box preceeding it has a value.

Me. cbotalukID.Enabled $=($ Not IsNull(Me.cbodistrictID $))$

End Sub

Private Sub Form_Load( )

'When the form loads, enable/disable the combo boxes. Combo boxes are only enabled if the preceeding combo box has a value.

EnableControls

End Sub

\section{c) Data base I/P details}

Here the database input details are required for the operator to search the customerrequirement as shown using $\mathrm{M} \mathrm{S}$ access softare screen as shown in Fig. 9 


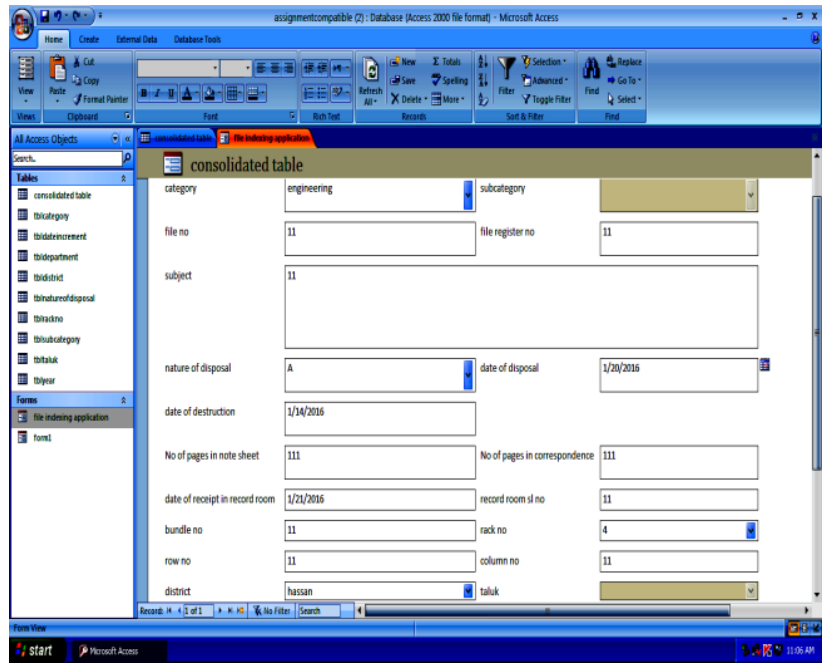

Fig .9 : Required Input source to software

\section{d) Details of requirement (out put)}

As per the input given to the software the output generated for the use of customer in the fallowing format of record room list is given in Table. 8 in last page.

\section{COMPARATIVE STUDY}

The comparison results of reduction of searching a file process time given by graphical method after the implementation of $5 \mathrm{~S}$ technology to a file searching process at record room of $\mathrm{CMC}$, hassan from previous to current status is as shown below. Figures 10, 11 and 12

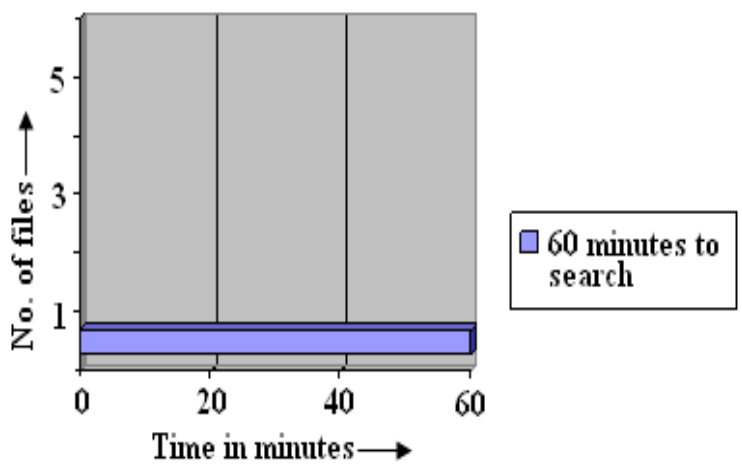

Fig .10 : File search before 5s application

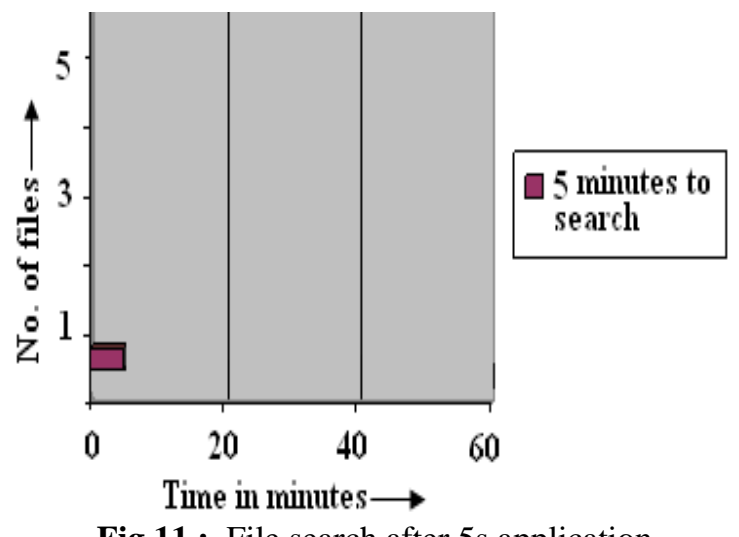

Fig.11 : File search after 5 s application

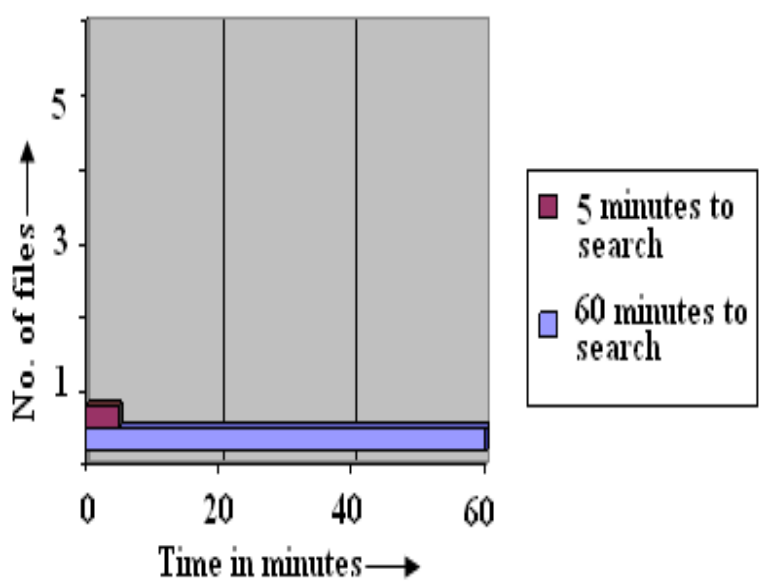

Fig .12 : File search comparison

\section{RESULTS AND DISCUSSIONS}

After the implementation of lean tools like 5S technology to the file searching process of CMC, Hassan, the total reduction time comparing with previous manual searching of file method is 60 minutes and after implementation of $5 \mathrm{~s}$ to file searching process using software application the total file searching time for the public(customer) is reduced to 5 minutes only. This increases the time efficiency in terms of $91.6 \%$. especially in public organization like CMC, Hassan , in this way the customer is getting maximum benefit using 5s application like segregation, labeling, checklist preparation, software application and closing of destructive files through the seiry, sheiton, shitsuke, seiketsu and seiso respectively. in this way simple changes in any process using lean manufacturing technology in supply chain activities can make better results and giving more satisfaction to the customer can achieve easily.

\section{FUTURE WORK}

The total study intension is to improve the CMC office from manual to computerized environment through the application of simple $5 \mathrm{~s}$ principle to their other work environments, which reduces the total time required for searching files. Which helps to reduce the process time in office relate to record room files. In other way we can use this lean and supply chain technology to other processes like health and safety projects like garbage maintenance, hygienic management for hotels in city, water distribution network to publics are more powerful factors to study and their improvement through the application of lean and supply chain principles with minimum changes in the existing process is more powerful tool for any of the small and medium organizations. This will also give more powerful satisfaction to the customers.

\section{CONCLUSION}

Implementation of lean manufacturig principle to the supply chain line activities can helps to reduce the waste in the small and medium enterprises for the betterment of the customer or publics through the reduction of manpower and their errors in terms of time, quality and perfection towards the customer views in smooth manner and also strong data 
management and their documentation can successfully achieved for the longer services to the publics with minimum expenditure is the main motive of this work.

\section{REFERENCES}

[1] Ananthanarayanan, K., (2006) Application of 5S Management System in NDE Laboratory. In: Proc. National Seminar on Non-Destructive Evaluation, Hyderabad, India.

[2] Brah SA, Chong WK (2004). Relationship between total productive maintenance and performance, Int. J. Prod. Res. 42(12): 2383-2401.

[3] Bayo-Moriones, A., A. Bello-Pintado, and J.M.D de Cerio (2010), 5S use in manufacturing plants: contextual factors and impact onoperating performance. International Journal of Quality \& Reliability Management,. 27(2): 217-230.

[4] Chapman, C.D., Clean house with lean 5S. Quality progress (2005) 38(6): 27-32.

[5] Chauhan et al.,(2010) Measuring the status of Lean manufacturing using $A H P$ " International journal of Emerging technology 1(2): 115-120.

[6] Gapp, R., R. Fisher, and K. Kobayashi(2008) Implementing $5 \mathrm{~S}$ within a Japanese context: an integrated management system. Management Decision, 46(4): 565-579.

[7] Hudli and Imandar (2010) Areas of Lean manufacturing for productivity improvement in a manufacturing unity", world academy of science, engineering and technology 69.

[8] Ho, S.K.M., Japanese (1999) 5-S - where TQM begins. The TQM Magazine, 11(5): 311-321.

[9] Ho, S.K., S. Cicmil and C.K. Fung, (1995) The Japanese 5-S practice and TQM training. Train. Qual., 3:19-24.DOI: 10.1108/09684879510098222

[10] Ho, S.K. and S. Cicmil(1996) Japanese 5-S practice. The TQM Magazine, 8(1): 45-53.
[11] J. Michalska, D. Szewieczek (2007) The improvement of the quality management by the activity-based costing, Journal of Achievements in Materials and Manufacturing Engineering 21(1): 9194.

[12] Kumar, M., et al. (2006) Implementing the Lean Sigma framework in an Indian SME: a case study. Production Planning and Control, 17(4): 407-423.

[13] Khedkar aet al.(2012) Study of implementing $5 S$ techniques in Plastic Moulding” International Journal of modern engineering research, 2(5): 3653-3656.

[14] Nilipour, A. and M. Jamshidian (2005) 5S As an Environmental Organization Management Tool; Benefits and Barriers. Proceedings of the 3rd International Management Conference, 2005, Dec 2025, Tehran, Iran.

[15] Prashant Koli. (2012) General Implementation and Calculation of $5 \mathrm{~S}$ Activity in any Organization" International journal of Science and Research, 1(3) : 229-232.

[16] P. Rai,(2016) "Effectiveness of 5S Implementation on Organizations Performance,"Abhinav International Monthly Refereed Journal of Research in Management \& Technology, 5(1)

[17] T. Karkoszka, D. Szewieczek (2007) Risk of the processes in the aspect of quality, natural environment and occupational safety, Journal of Achievements in Materials and Manufacturing Engineering $20: 539-542$.

[18] R. S. Agrahari, P.A. Dangle, K.V.Chandratre (2015), Implementation Of 5S Methodology In The Small Scale Industry: A Case Study" international journal of scientific \& technology research,4(4) : 180-187, issn 2277-8616

[19] Ravi Chourasia, Dr. Archana Nema (2016), Review on Implementation of $5 \mathrm{~S}$ methodology in the ServicesSector,International Research Journal of Engineering and Technology (IRJET) e-ISSN: 239500563(4),:1245-1249.

Table 8: Output Record room list of 2011-2012

\begin{tabular}{|l|l|l|l|l|l|l|l|l|}
\hline Sl.no. & $\begin{array}{l}\text { File } \\
\text { category }\end{array}$ & $\begin{array}{l}\text { Sub } \\
\text { category }\end{array}$ & File year & File no. & Taluk & Hobli & Village & Sub \\
\hline 1 & Revenue & $\begin{array}{l}\text { Hakku } \\
\text { vargavane }\end{array}$ & $2010-11$ & $\begin{array}{l}\text { W-34 } \\
\text { SAS } 888\end{array}$ & Hassan & & & $\begin{array}{l}\text { Rakha } \\
\text { Ramesh }\end{array}$ \\
\hline
\end{tabular}

Contd.---

\begin{tabular}{|l|l|l|l|l|l|l|l|l|l|}
\hline $\begin{array}{l}\text { Nature of } \\
\text { disposal }\end{array}$ & $\begin{array}{l}\text { Date of } \\
\text { closure }\end{array}$ & $\begin{array}{l}\text { Total } \\
\text { page }\end{array}$ & $\begin{array}{l}\text { Total } \\
\text { column }\end{array}$ & $\begin{array}{l}\text { Date of } \\
\text { destruction }\end{array}$ & $\begin{array}{l}\text { Receipt } \\
\text { date }\end{array}$ & $\begin{array}{l}\text { Room } \\
\text { sl.no }\end{array}$ & $\begin{array}{l}\text { Bundle } \\
\text { sl.no }\end{array}$ & $\begin{array}{l}\text { row } \\
\text { no. }\end{array}$ & $\begin{array}{l}\text { Column } \\
\text { no. }\end{array}$ \\
\hline B & $\begin{array}{l}25-09- \\
2011\end{array}$ & 15 & 0 & $25-09-2011$ & $\begin{array}{l}25-09- \\
2011\end{array}$ & 1 & 1 & 1 & 1 \\
\hline
\end{tabular}

